\title{
A case of fulminant necrotising fasciitis
}

\author{
Kelsey van Son, ${ }^{1}$ Claudia Savelkoul, ${ }^{2}$ Roland Mollen, ${ }^{3}$ David HT Tjan ${ }^{2}$
}

${ }^{1}$ Emergency Department Gelderse Vallei Hospital, Ede The Netherlands ${ }^{2}$ Department of Intensive Care, Gelderse Vallei Hospital, Ede, The Netherlands ${ }^{3}$ Department of Surgery, Gelderse Vallei Hospital, Ede, The Netherlands

\section{Correspondence to} David HT Tjan, tjand@zgv.nl

KS and CS contributed equally.

Accepted 27 March 2017

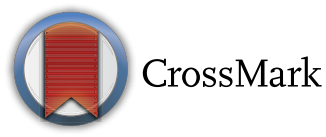

To cite: van Son $K_{\text {, }}$ Savelkoul C, Mollen R, et al. BMJ Case Rep Published Online First: [please include Day Month Year]. doi:10.1136/bcr-2016219142

\section{DESCRIPTION}

A 57-year-old man presented to the emergency department with fever, chills and a wound on his

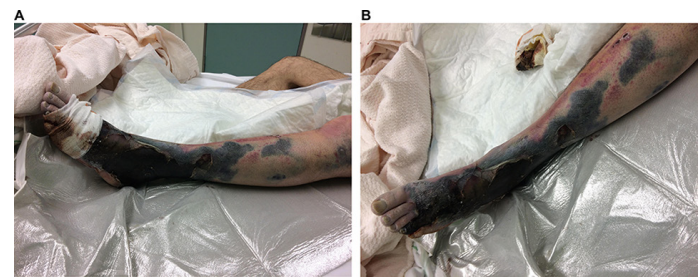

Figure $1(A, B)$ The extension of necrotising fasciitis of the left lower extremity.

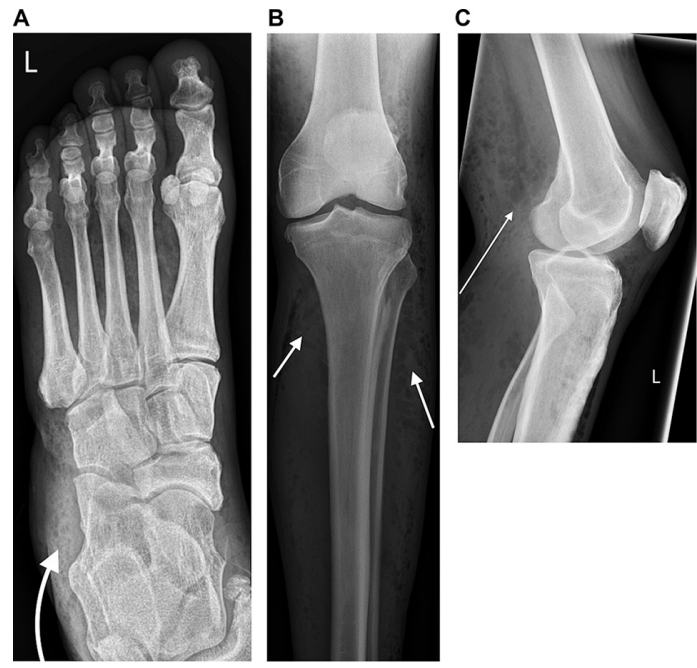

Figure 2 X-rays of the foot (A) and knee (B and C) showing subcutaneous air (arrows), which is typical of necrotising fasciitis.

A

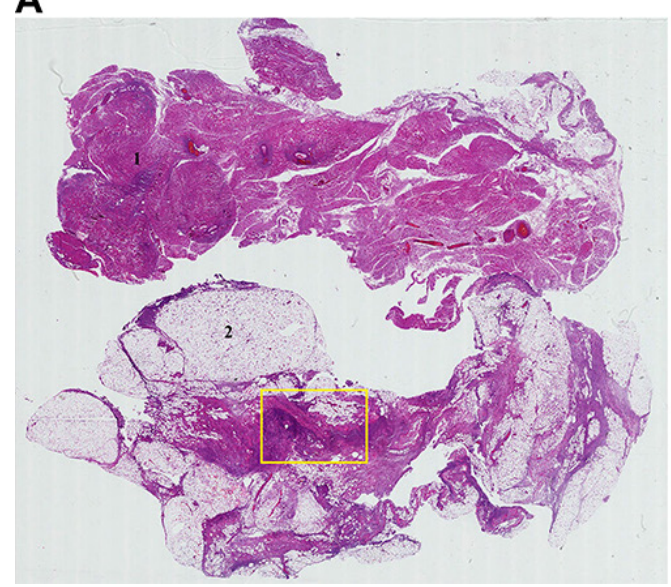

B

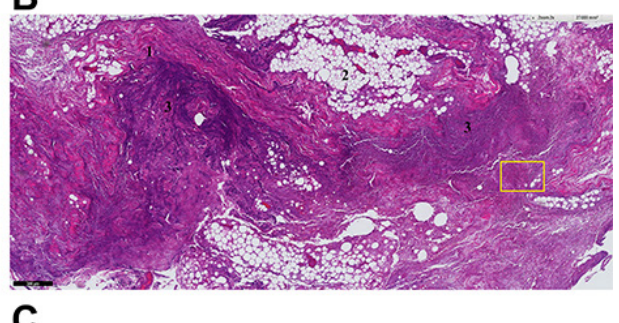

C

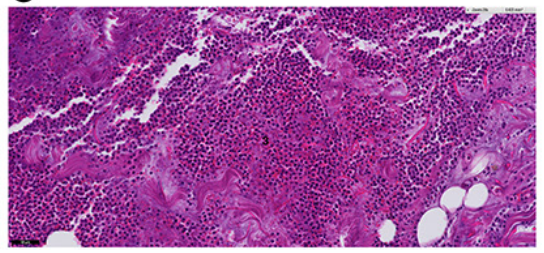

Figure 3 (A) Overview of tissue from the left lower extremity affected by necrotising fasciitis showing fascia (1) and fat tissue (2). (B) The infiltrate (3) is localised next to the fascia (1). (C) The infiltrate (3) contains neutrophils, which implies bacterial infection. A pathology analysis contributes to the clinical diagnosis of necrotising fasciitis. 


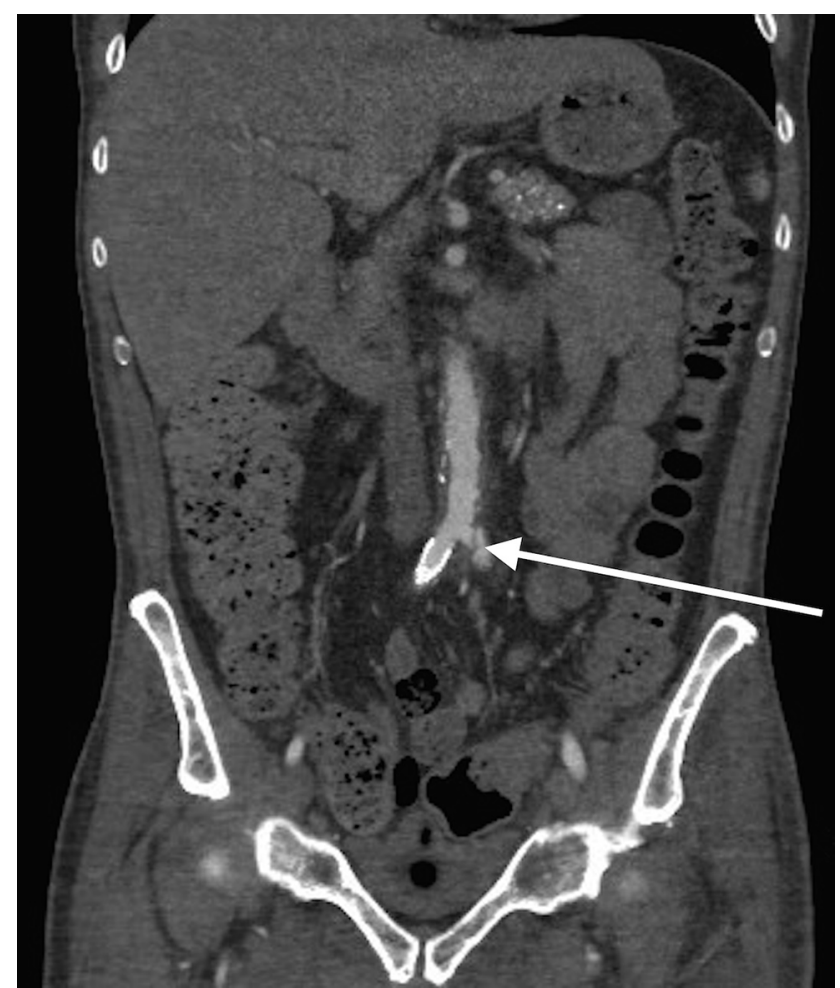

Figure 4 CT scan showing a stenosis (arrow) of the common and external left iliac artery left.

\section{Box Risk factors for necrotising fascititis}

Immunosuppression: medication (such as steroids, chemotherapy, infliximab) or disease (AIDS, malignancy, tuberculosis) induced

Cardiovascular diseases: arteriosclerosis, congestive heart failure, renal failure

Trauma: fractures, surgery, insect/animal bites, frostbite, intravenous drug abuse

Skin diseases: systemic lupus erythematosus, abscess, psoriasis, varicella

Gastrointestinal: diverticulitis, perirectal abscess or perforated viscus

Other: diabetes mellitus, obesity, pregnancy, advanced age
Table 1 Bacteria causing necrotising fasciitis

Gram-negative

\begin{tabular}{|c|c|c|}
\hline Gram-positive aerobic bacteria & aerobic bacteria & Anaerobic bacteria \\
\hline Group A $\beta$-haemolytic streptococci & Escherichia coli & Bacteroides spp \\
\hline Group B streptococci & $\begin{array}{l}\text { Pseudomonas } \\
\text { aeruginosa }\end{array}$ & Clostridium spp \\
\hline Enterococci & Proteus spp & Peptostreptococcus spp \\
\hline $\begin{array}{l}\text { Coagulase negative staphylococci } \\
\text { Staphylococcus aureus }\end{array}$ & Serratia spp & \\
\hline Bacillus spp & & \\
\hline
\end{tabular}

\section{Learning points}

- Provide adequate instructions to patients with wounds in order to prevent unnecessary extension and impairment; especially in patients with risk factors, such as diabetes and smoking.

- Necrotising fasciitis is an uncommon but potentially fatal condition especially if unrecognised.

- Management should consist of immediate resuscitation, early surgical debridement and administration of broad spectrum intravenous antibiotics.

Contributors KvS is responsible for admitting the patient to the hospital participated i $n$ writing the article (and revision), and received informed consent from the patient. CS is responsible for care of the patient in the ICU and participated in writing the article (and revision). DHTT is responsible for care of the patient in the ICU and critically revised the article. RM is responsible for surgical care of the patient and critically revised the article. KvS and CS are guarantors.

Competing interests None declared.

Patient consent Obtained.

Provenance and peer review Not commissioned; externally peer reviewed. (C) BMJ Publishing Group Ltd (unless otherwise stated in the text of the article) 2017. All rights reserved. No commercial use is permitted unless otherwise expressly granted.

\section{REFERENCES}

1 Van S, De VJ, Bijker JB, et al. Review of 58 patients with necrotizing fasciitis in the Netherlands. World J Emerg Surg 2016;11:7-12.

2 Corona PS, Erimeiku F, Reverté-Vinaixa MM, et al. Necrotising fasciitis of the extremities: implementation of new management technologies. Injury 2016;47(Suppl 3):S66-S71.

3 Singh G, Bharpoda P, Reddy R. Necrotizing fasciitis: a study of 48 cases. Indian J Surg 2015;77:345-50

Copyright 2017 BMJ Publishing Group. All rights reserved. For permission to reuse any of this content visit

http://group.bmj.com/group/rights-licensing/permissions.

BMJ Case Report Fellows may re-use this article for personal use and teaching without any further permission.

Become a Fellow of BMJ Case Reports today and you can:

- Submit as many cases as you like

- Enjoy fast sympathetic peer review and rapid publication of accepted articles

- Access all the published articles

- Re-use any of the published material for personal use and teaching without further permission

For information on Institutional Fellowships contact consortiasales@bmjgroup.com

Visit casereports.bmi.com for more articles like this and to become a Fellow 